\title{
Barbiturate Drug Class Measurement
}

National Cancer Institute

\section{Source}

National Cancer Institute. Barbiturate Drug Class Measurement. NCI Thesaurus. Code C74688.

The determination of the amount of barbiturate class agents present in a sample. 